\title{
GMO Corn in México: Precaution as Law's Decolonial Option
}

\author{
Ernesto A. Hernández-López \\ Fowler School of Law, Chapman University, United States
}

\begin{abstract}
For over six years now, the law has been central to policy debates about genetically modified organism (GMO) corn in México, the birthplace of maíz (corn). In the lawsuit Colectividad del Maíz, the domestic courts have shaped the policy on GMO corn. Out of concern for biodiversity, the courts have suspended regulatory approval for commercial GMO corn permits needed by seed companies. This article uses decolonial theory to examine how the law can both encourage and limit the use of GMOs. Decolonial perspectives isolate how economics, legal authorities, and ideologies work in unison to shape relations between the Global South and private interests. This is accomplished by defining the subject of any such legal regulations. Different legal doctrines treat GMOs in different and distinct ways. Under the doctrines of biosecurity, intellectual property, and international trade law, markets and biotechnology benefit as the subject of the law. Such doctrines disenfranchise maíz nativo (non-GMO corn) by making it the law's object. The article also adopts Bruno Latour's theory of “down to earth" politics to identify important changes in GMO regulations. Collective action litigation has limited the expansion of GMO corn via the application of precautionary principle measures and motivated new legislation in México.
\end{abstract}

Keywords: GMO, corn, biotechnology, international trade, agriculture, Global South.

\section{Introduction}

This article describes the dynamics of law and technology in controversies over genetically modified organism (GMO) corn and biodiversity in México, the birthplace of maíz (corn). ${ }^{1}$ It uses decolonial theory ${ }^{2}$ as a method to identify the mutual influence between law and technology. Decolonial theory isolates how economics, legal authorities, and ideologies work in unison to shape relations between the Global North, the Global South, and private interests. ${ }^{3}$ To spread overseas, GMOs and biotechnologies require favorable regulations, both domestically and internationally, and corresponding conceptual support. This article also employs Bruno Latour's proposal for "down to earth" politics to pinpoint significant changes in Mexican maíz policy. ${ }^{4}$

This article focuses on a collective action lawsuit, the Colectividad del Maíz, which is being litigated in domestic Mexican courts. ${ }^{5}$ Since 2013 , the courts have made orders temporarily suspending commercial GMO corn permits in México. ${ }^{6}$ This article argues that the Colectividad del Maíz dispute represents a turning point that could potentially shift the course of México's

\footnotetext{
${ }^{1}$ Alma Piñeyro Nelson notes that the public controversy in relation to GMO corn began in 2001 in México and emphasizes the scientific, cultural, legal, political, and thus epistemic perspectives, see "Un ejemplo de controversia científica," 91.

${ }^{2}$ Moraña, Coloniality at Large, 2.

${ }^{3}$ This paraphrases coloniality and its "matrix of power," see Mignolo, "Introduction," 155.

${ }^{4}$ Latour, Down to Earth, 2.

${ }^{5}$ The class action remains unresolved; however, the court orders remain in place, see Concha "Siete años defendiendo el maíz."

6 This court order states: Nota Informativa, Acción colectiva contra la autorización de la liberación para comercializar maíz transgenico DGCS/NI: 41/2013, 14-10-2013. The United States (U.S.) Department of Agriculture Foreign Agriculture Service described this dispute as in "legal stalemate" after "activists" filed a class action on July 5, 2013. In September 2013, a judge ordered a stop to the experimental and commercial planting of GMO corn, see U.S. Department of Agriculture, Foreign Agriculture Service (2018).
}

Except where otherwise noted, content in this journal is licensed under a Creative Commons Attribution 4.0 International Licence. As an open access journal, articles are free to use with proper attribution. ISSN: 2652-4074 (Online) 
biosecurity policies. The plaintiffs, La Colectividad (the collective), ${ }^{7}$ argue that GMO corn irreversibly threatens biodiversity and thus México should not authorize commercial permits for GMO seeds. Notably, La Colectividad further argues that the unauthorized release of GMOs violates a right to sustainably enjoy biodiversity and consume non-GMO corn. For over six years now, the courts have ordered that the government, specifically the Secretary of Agriculture, ${ }^{8}$ temporarily suspend any reviews and approvals of commercial permits for GMO corn. These orders have affected seed companies such as Monsanto, Dow-Pioneer, and Syngenta. ${ }^{9}$

The Colectividad del Maíz dispute illustrates the various legal perspectives on GMOs. Thus far, the courts have taken the view of the Colectividad that GMO genomes pose serious risks to landrace corn (i.e., non-GMO plants, or as it is referred to in México, maíz nativo). ${ }^{10}$ The Colectividad's perspective ${ }^{11}$ emphasizes legal protections for biodiversity that reflect conceptual assumptions focused on communal interests and preventative measures (i.e., the incorporation of the precautionary principle). ${ }^{12}$ Notably, México represents the source of origin of and has the greatest diversity in corn, ${ }^{13}$ which is maintained by traditional farming practices. ${ }^{14}$ GMOs threaten México's 59 corn varieties. ${ }^{15}$ For millions of Mexicans, corn is more than a daily staple, it is also a powerful link to indigenous cultures. ${ }^{16}$ With México's Supreme Court posed to review the court orders, the lawsuit represents a potential shift in domestic regulations on GMO corn.

Opposing legal positions stress protection for individual rights and the management of transgene risks. For over three decades, seed companies and governments have relied on economic justifications, permissive doctrines, and conceptual rationalizations to facilitate GMOs. Seed companies and regulators argue that GMOs are safe and point to the default positions in México's biosecurity law, the Ley de Bioseguridad de Organismos Genéticamente Modificados (LBOGM). This law creates a default for GMO authorization, as it includes evidentiary and regulatory hurdles that limit when precautionary principle measures are applied. Commentators call for GMO corn to be cultivated in México. ${ }^{17}$ Scientific studies have raised doubts as to whether GMO transgenes can penetrate landraces, ${ }^{18}$ arguing that GMOs increase the productivity of the corn plant. ${ }^{19}$ As a lawsuit focused collective action, the Colectividad has avoided a number of the hurdles introduced by the LBOGM. ${ }^{20}$

This article uses decolonial theory to illustrate the mutual influence between biotechnology and the law. This critical theory isolates how dueling positions emphasize different economic, regulatory, and conceptual assumptions. Further, this article argues that a legal victory for the Colectividad would represent re-grounded opposition to globalization and modernity, as called for by Latour. ${ }^{21}$ This implies a new form of advocacy that is referred to as "down to earth" politics. Public sentiment regarding the lawsuit has fueled opposition against the North American Free Trade Agreement's (NAFTA) revision to the United States Mexico Canada Agreement (USMCA, 2020), referred to in Spanish as T-MEC. The USCMA protects trade and investments in biotechnology in México. Recent Mexican legislation has tried to oppose support for biotechnology. A future policy banning GMO corn would reverse a default position under the law that encourages biotechnology. If such policy changes were to occur,

\footnotetext{
${ }^{7}$ This essay refers to the collective as the Colectividad and the dispute as the Colectividad del Maíz. The Colectividad is formed by 53 persons, who filed a demanda colectiva, a document similar to a class action, in which it sought orders to stop the Mexican government from authorizing permits to plant GMO corn. For further details on this entity, see Colectividad Demandante. The Colectividad del Maiz is also referred to as the Colectiva del Maíz or Acción Colectiva del Maíz.

${ }^{8}$ For the sake of simplicity this article uses the name Secretary of Agriculture, even though over the six years of litigation its name in Spanish has changed from the Secretaría de Agricultura, Ganadería, Desarrollo Rural, Pesca y Alimentación (SAGARPA) to Secretaría de Agricultura y Desarrollo Rural (SADER).

${ }^{9}$ A number of seed companies have consolidated. Bayer merged with Monsanto, ChemChina merged with Syngenta, and Corteva was created following the Dow and Pioneer-Dupont merger. For simplicity, this article uses the names most common in court documents and new analysis in México (i.e., Monsanto, Dow, Pioneer-Dupont, and Syngenta).

${ }^{10}$ Fitting, The Struggle for Maize, 40.

${ }^{11}$ Demanda colectiva del maíz, El devenir de la demanda de acción colectiva (complaint from the collective action), (July 5, 2013).

12 Cartagena Protocol on Biosafety to the Convention on Biological Diversity, preamble, 2, (January 29, 2000); U.N. Conference on Environment and Development, Rio Declaration on Environment and Development, Principle 15, (June 14, 1992).

${ }^{13}$ Piñeyro-Nelson, "Transgenes in Mexican Maize," 750

${ }^{14}$ Nadal, "Mexico's Corn-Producing Sector," 34-35.

15 Rodriguez, "59 variedades de maíz mexicano."

${ }^{16}$ Corn is México's main agricultural crop in terms of production and crop area and the main source of energy and nutrients in the country. The consumption of corn in Mexico is six times that of the world average, see Gutiérrez González, The Protection of Maize, 57. Nelson, Transgenes in Mexican Maize, describes the epistemic and cultural threats posed by GMO corn in "Un ejemplo de controversia científica."

${ }^{17}$ Excelsior, "Monsanto aclara."

18 Ortiz-García. "Letter to the Editor."

${ }^{19}$ Pellegrino, "Impact of Genetically Engineered Maize."

${ }^{20}$ For a comparison of México's collective action law and the LBOGM, see Hernández-López, "GMO Corn in México."

${ }^{21}$ Latour, Down to Earth, 2.
} 
the law would be re-oriented to focus on biodiversity and the protection of maíz (an approach that would differ to that adopted under the LBOGM and USMCA, which support biotechnology).

This article is divided into three sections. Part I describes decolonial theory, the idea of coloniality, and its manifestation in economics, authority, and subjectivity. It uses Latour's proposal for "down to earth" politics as a way to identify relevant changes in maiz policy. ${ }^{22}$ Part II explains how GMOs benefit from regulatory assumptions under Mexican law. The LBOGM creates legal hurdles. It makes it difficult to apply any precautionary principle measures. The subjects of the LBOGM perspective on the biotechnology regulations are intellectual property (IP) and risk management. Conversely, the subjects of precautionary principle measures are biodiversity and landrace corn. Part III describes how GMO corn controversies create opportunities for the adoption of decolonial approaches and down to earth politics. The Colectividad has inspired widespread public support against GMO corn in México. The public sentiment has encouraged legislation attempting to secure some of the precautionary gains achieved through the litigation. Further, these legislative efforts have attempted to counter support for GMO protections under the USMCA.

\section{Part I: Coloniality and Down to Earth Politics}

This article uses decolonial theory to show how coloniality fuels economics, law, and concepts in support of GMO corn. Similarly, it uses Latour's call for down to earth politics to identify the significance of potential changes in maíz policies. This perspective helps show how regulations and policies could focus on biodiversity. Taken together, these two approaches are first used to illuminate how GMO technology is encouraged and then used to identify how policy change could eliminate this support.

Latin American scholars use decolonial theory to examine colonial influence in the region, even though most of the region attained independence from formal colonialism over two centuries ago. ${ }^{23}$ Two decolonial perspectives state that: 1) colonialism is central to modernity (both historically and presently); and 2) foreign interests seek to capitalize on this ideology and material justification to ensure its continued influence. ${ }^{24}$ Decolonial analyses examine the interplay and persistent influence of history, economic choices, and conceptual framings. Such analyses seek to show that cultural, governmental, and material forces are not entirely separate, but are interrelated or dependent on each other. As discussed further below, GMO farming derives economic support via the provision of legal protections for international trade and IP, authority in the form of regulatory approvals and permissive institutions, and conceptual assumptions that high yield crops are better.

The notion of coloniality isolates how colonial influence persists when formal colonialism ends. ${ }^{25}$ Peruvian sociologist Anibal Quijano developed the term "coloniality," which has become a central point of analysis for decolonial scholars. ${ }^{26}$ Coloniality describes how global or foreign forces continue to shape many events in the region. ${ }^{27}$ Coloniality emphasizes that Latin America is not just a legacy of colonialism with a colonial past. ${ }^{28}$ Indeed, in broad strokes, coloniality has persisted in the region since the colonial occupation, after which it continued into the nineteenth century liberal period and through the Cold War (which saw the rise of developmentalist states) and the period of neoliberalism. It continues to persist today. In Latin America, global forces have relied on coloniality for over two centuries since decolonization and for over five centuries since 1492 . Seen as a methodology, coloniality represents a process that persists and not a condition that ends. ${ }^{29}$ In resisting coloniality, local communities have continually sought (and continue to seek today) sovereignty and emancipation. ${ }^{30}$

Coloniality operates within a "matrix of power" and exercises control over four domains: economics, authority, patriarchy, and knowledge and subjectivity. ${ }^{31}$ Walter Mignolo has elaborated on each of these domains. For example, the economics domain refers to how foreign actors have acquired land, exploited labor, and appropriated natural resources. ${ }^{32}$ The authority domain refers to control over public institutions. ${ }^{33}$ This article argues that laws and regulations are one such institution. The patriarchy

\footnotetext{
${ }^{22}$ Latour, Down to Earth, 2.

${ }^{23}$ Coronil, "Naturaleza del poscolonialismo," 87-112.

${ }^{24}$ Moraña, Coloniality at Large, 2.

${ }^{25}$ Moraña, Coloniality at Large, 2, 6, fn 11; Quijano, "Coloniality and Modernity/Rationality," 170.

${ }^{26}$ Quijano, "Coloniality of Power," 533.

${ }^{27}$ Quijano, "Coloniality of Power," 533.

${ }^{28}$ Moraña, Coloniality at Large, $11,13,16$.

${ }^{29}$ Grosfoguel, "Decolonizing Post-Colonial Studies," 13.

${ }^{30}$ Grosfoguel, "Decolonizing Post-Colonial Studies," 10.

${ }^{31}$ Quijano, "Coloniality of Power," 533; Mignolo, "Introduction," 155-156.

${ }^{32}$ Mignolo, "Introduction," 155-156.

${ }^{33}$ Mignolo, "Introduction," 155-156.
} 
domain dictates how gender, sexuality, and family life are experienced. ${ }^{34}$ Finally, the knowledge and subjectivity domain shows how knowledge is colonized. This article refers to this as the "subject-knowledge domain." It emphasizes the influence that subjects articulate in the framing of legal norms. Thus, coloniality shapes expressions, beliefs, and references to the supernatural..$^{35}$ It delineates who is a subject and who shapes knowledge. ${ }^{36}$ A subject produces knowledge, perspectives, images, and idea systems. Further, coloniality also simultaneously classifies who is an object and does not produce knowledge.

By way of an example, for centuries, Spanish monarchs, far away in Europe, ruled over large populations in the Americas by controlling labor and resources and exercising sovereign and violent authority. The monarchy benefitted from Christianity justifying and structuring ideas about nature and humans. Spain capitalized on how these references were made to shape political, economic, and religious control. Spain profited from ideologies, such as mercantilism over commerce, the notion of empire to acquire territory and rule over populations, and Christianity to inform legal, domestic, sexual, and environmental views. Coloniality made indigenous communities objects in knowledge production. These communities did not produce, as subjects would, how knowledge was used in economic, political, or religious systems. Complex belief systems existed throughout the Americas before colonialism. For centuries, coloniality allowed Spain to rule over terrain and peoples and respond to local resistance.

The notion of coloniality helps identify how state power (authority), concepts (subject-knowledge), and economics work together. Ramón Grosfoguel explains how this transpires. ${ }^{37}$ As a matrix, coloniality masks how hierarchies shift when resistance develops. This creates multiple jurisdictions or locations in which opposition manifests. ${ }^{38}$ For example, Quijano notes how, early in the Spanish empire, the notion of race was created to divide labor classes and accumulate capital for monarchs. ${ }^{39}$

For this article, coloniality's "matrix of power" provides a methodological framework. It identifies the economics and material incentives at play, the legal instruments and doctrine that inform authority, and the use of subject-knowledge to justify legal choices. These three steps isolate coloniality's domain over economics, authority, and subject-and-knowledge, respectively. This does not apply to the patriarchy domain. Undoubtedly, maíz is used along gendered terms, as it is important for households and health. ${ }^{40}$ Focusing on the Colectivadad, the article only examines three domains.

Coloniality helps explain the spread of GMOs. Biotechnologies depend on the subject-knowledge domain being framed to favor industry needs. ${ }^{41}$ These technologies have economic value when IP owners possess the legal means to enforce their rights. IP owners benefit as subjects in legal regimes that address biosecurity and trade policies. This gains geopolitical significance when the Global South further fosters seed companies' interests, rather than engaging in sovereign efforts to protect biodiversity. The biotechnology industry relies on cross-border governance that shields its legal benefits while disenfranchising legal claims for those who lack IP rights. Sheila Jasanoff describes biotechnology as part of empire making. ${ }^{42}$ These technologies try to impose ideologies with an emphasis on regulations that protect individual liberties and the movement of goods and services.

Decolonial perspectives focus on conceptual changes and the evolution of transnational forces. Latour has called for similar modifications to combat climate change, noting that environmental catastrophes result from three phenomena: deregulation across the globe, socioeconomic and political inequalities, and ideologies that deny environmental harm. ${ }^{43}$ The election of Donald Trump and other populists worldwide exemplifies the force of these ideologies. Notably, these three phenomena work together and defy strategies to address climate change.

Latour's perspective is similar to a decolonial approach. Both examine how power is exercised over multiple domains. Specifically, Latour's description of deregulation corresponds to an authority domain, inequality matches an economic domain, and climate change denial resembles a subject-knowledge domain. Thus, both approaches (i.e., decolonialization and Latour's down to earth politics) point to interrelated forces (governmental, economic, and ideological). Both present their affects across international borders and emphasize similar ways to identify problems.

\footnotetext{
${ }^{34}$ Mignolo, "Introduction," 155-156.

${ }^{35}$ Quijano, "Coloniality of Power," 533.

${ }^{36}$ Quijano, "Coloniality and Modernity/Rationality," 172-174.

37 Grosfoguel, "Decolonizing Post-Colonial Studies," 13.

${ }^{38}$ Grosfoguel, "Decolonizing Post-Colonial Studies," 13.

${ }^{39}$ Quijano, Coloniality of Power," 533.

${ }^{40}$ Emma Gaalas Mullaney uses feminist scholarship in geopolitics to examine the significance of corn, see Mullaney, "Geopolitical Maize."

${ }^{41}$ For a decolonial analysis of intellectual property, GMOs, and biotechnology, see Vats, "Critical Race IP," 790-791; Castro-Gómez, La Poscolonialidad Explicada a Los, 83.

${ }^{42}$ Jasanoff, "Biotechnology and Empire," 277.

${ }^{43}$ Latour, Down to Earth, 34.
} 
This article uses Latour's proposal of down to earth politics to identify significant changes in Mexican corn policies and potential responses to the harms created by coloniality. The notion of down to earth politics isolates how policy and regulations can effectively limit the support from which GMO technologies benefit. Notably, Latour calls for a terrestrial approach to environmental advocacy and geopolitics. ${ }^{44}$ Terrestrial refers to a view that the earth is an active agent and responds to human activity. ${ }^{45}$ Latour proposes a terrestrial approach to move away from anthropomorphic assumptions that humans are not embedded in nature and do not depend on the earth. Under a terrestrial approach, the earth is no longer seen as a resource to be exploited or as being independent of culture. Latour contents that politics should "come down to earth," be attached to the soil and recognize that human existence depends on more than human action. ${ }^{46}$ As described below, national corn policies and legal disputes about corn in México resemble a terrestrial shift to protect and nurture corn's biodiversity.

\section{Part II: Precaution Faces Regulations that Fuel GMOs}

In México, GMO regulations effectively protect private interests in biotechnology by relying on conceptual assumptions. Biotechnology benefits from the belief that high yield crops are better. Similarly, protections in biosecurity, international trade, and IP law doctrines serve biotechnology. This section contends that this as an example of coloniality. The goal of maximizing corn farm outputs operates as the economic domain. Biosecurity law procedures function as the authority domain. Legal debates between precaution and risk management shape the subject-knowledge domain.

\section{a. Precaution in the "Ley Monsanto"}

On its face, the LBOGM regulates GMOs, controls any associated harms, and contains precautionary principle powers. In 2005 , México passed the LBOGM to regulate GMOs, pursuant to international law ${ }^{47}$ that had been agreed to at the United Nations (U.N.) Convention on Biodiversity (CBD) (1992) ${ }^{48}$ and in the Cartagena Protocol (2000). ${ }^{49}$ The Cartagena Protocol is the main international treaty on GMOs. ${ }^{50}$ The LBOGM's primary objective was to simplify biosecurity regulations as requested by private interest groups after a de facto moratorium on GMOs had been in place since $1999 .{ }^{51}$

The LBOGM's creation was motivated more by political and private economic interests than scientific studies, or social or environmental concerns. ${ }^{52}$ Mexican experts in corn from a variety of science fields contend that the LBOGM privileges biotechnology while excluding input from diverse science fields, ecology, anthropology, and environmental sciences. ${ }^{53}$ Following a long line of neo-liberal reforms, the LBOGM simplified the regulations to attract biotechnology investments. ${ }^{54}$

The LBOGM contains substantive regulations on the harms related to GMO cultivation. The Secretary of Agriculture reviews and approves or denies any permits for GMO planting, and requests for experimental, pilot, or commercial plots. ${ }^{55}$ For each permit, a risk assessment is conducted on a case-by-case basis. Alicia Gutiérrez González criticizes the LBOGM for failing to define what constitutes a risk. ${ }^{56}$ She further argues that the LBOGM does not permit México to identify risks when there is a lack of knowledge regarding the technology. ${ }^{57}$ The diversity and origin criteria, which are specifically required for corn protection, were never precisely defined by the LBOGM. ${ }^{58}$ Similarly, the LBOGM mandates a specific regime to protect corn. ${ }^{59}$

\footnotetext{
${ }^{44}$ Latour, Down to Earth, 40, 63.

${ }^{45}$ Latour, Down to Earth, 40.

${ }^{46}$ Latour, Down to Earth, 92.

47 Serratos Hernández, "Bioseguridad y dispersión de maíz," 136. For a general description of corn regulations in accordance with GMO protections pursuant to the CBD and Cartagena Protocol, see Peralta, "La protección official," 441-443.

${ }^{48}$ Convention on Biodiversity.

${ }^{49}$ Cartagena Protocol; Gupta, "The Influence of the Cartagena Protocol," 33.

${ }^{50}$ Specifically, the Protocol addresses "living modified organisms." Cartagena Protocol, art 3(k). The Protocol was signed by 103 countries and was supported by pro and anti-GMO positions. The U.S. did not agree to it, but was heavily involved in its negotiations; see Applegate, "The Taming of the Precautionary Principle," 63 and n. 209; McAfee, "Corn Culture and Dangerous DNA," 30.

${ }^{51}$ Serratos Hernández, "La ley de bioseguridad y," 134.

52 Álvarez-Buylla, El maíz en peligro ante los transgénicos, 111.

${ }^{53}$ Serratos Hernández, "Bioseguridad y conservación del maíz,” 258; Olivé, "Ética y transgénicos,” 321.

${ }^{54}$ Serratos Hernández, "Bioseguridad y conservación del maíz," 266. For a description of this framework, the USDA issues an annual report on biotechnology in México, "Mexico: Agricultural Biotechnology Annual." For a more detailed summary of the LBOGM legislative history, and its process for devising new regulations, see Herrera Izaguirre, "Mexico's Environmental Law," 140-55.

${ }^{55}$ LBOGM, arts. 60-65.

${ }^{56}$ Gutiérrez González, The Protection of Maize, 124-25.

57 Gutiérrez González, The Protection of Maize, 124-25.

${ }^{58}$ Antal, "Interacción entre política, ciencia y sociedad en biotecnología," 43.

${ }^{59}$ LBOGM, art. 2:XI.
} 
The LBOGM contains precautionary principle norms ${ }^{60}$ Enshrined in the CBD and other treaties, the precautionary principle allows states to implement measures to protect biodiversity even in the absence of scientific evidence of any harm. ${ }^{61}$ The Cartagena Protocol includes a precautionary principle specific to biotechnology in Article 10:6 $6^{62}$ that allows states to take "socio-economic considerations" into account in employing precautionary measures and assessing biodiversity. ${ }^{63}$ It adds that a "Lack of scientific certainty due to insufficient relevant scientific information and knowledge ... shall not prevent [a country] from [rejecting transgenic imports]." Kathleen McAfee explains that despite these articulated powers, states must justify their precautionary measures with what is "sound science." 64 The LBOGM refers to precautionary principle powers specific to GMOs, ${ }^{65}$ and contains powers to designate protections for "centers of origin" and "centers of diversity" 66 and to designate GMO free zones. ${ }^{67}$ This is consistent with Cartagena Protocol norms. ${ }^{68}$ These powers are contained in article 9:IV of the LBOGM. ${ }^{69}$

Despite these provisions, the LBOGM creates a legal opening for GMOs in its exceptions to precautionary protections, the conflicting objectives of the regime, and the limited scope of the corn regime. ${ }^{70}$ Consequently, it is called "La Ley Monsanto" by many, which means Monsanto's law. ${ }^{71}$ The first criticism is that the LBOGM's precautionary principle has a minimal effect because of the significant exceptions. Article 9:IV articulates precautionary reservations, but it lacks any explicit guidance on what measures can be taken or from where this authority derives. ${ }^{72}$ Mexican experts have criticized these precautionary protections as discretionary, as they limit these powers to what is "in accord with [México's] capacities." "73 The fear is that the language about capacities will be used as a justification to find that Mexican regulators cannot properly assess the risk.

The LBOGM specifically creates significant exceptions to precautionary principle measures. It states that any precaution must "take into account [México's] international obligations."74 There is a fear that the lack of guidance coupled with the requirement to comply with other international obligations could open the door to exceptions. The Mexican government and seed companies could argue that international economic obligations preempt precaution. These obligations could arguably be for rights afforded for trade in the NAFTA or the World Trade Organization Agreement on Trade-Related Aspects of Intellectual Property Rights (TRIPS $)^{75}$ These fears (described in greater detail in Part III of this article) focus on how the USMCA makes precautionary measures more difficult to enact, while creating regulatory protections for trade in biotechnology.

The second criticism is that the LBOGM has conflicting objectives for regulating and encouraging GMOs. Specifically, it is argued that the LBOGM aims to regulate GMO agriculture and its environmental impacts. ${ }^{76}$ This conflicts with the LBOGM's objectives to support research in GMOs. For example, in relation to the secondary focus in the regulatory environmental role allotted to the Secretary of the Environment and Natural Resources, this agency does not issue permits or review petitions for them; rather, it only consults in the process. Thus, the permit process emphasizes perceived agricultural needs over biodiversity and environmental objectives. Leading Mexican scientists have identified these contradictions in a various LBOGM articles. ${ }^{77}$

The third criticism is that the LBOGM's special corn regime does not provide sufficient protection for biodiversity. This corn regime is seen as insufficient for various reasons. ${ }^{78}$ The LBOGM's maps mandate protections from GMO farming at specific geographic locations. One complaint is that by categorizing locations as either "centers of origin" or "centers of diversity" in these regulatory maps, only one type of protection can be extended to any one location. ${ }^{79}$ Specifically, it has been argued that

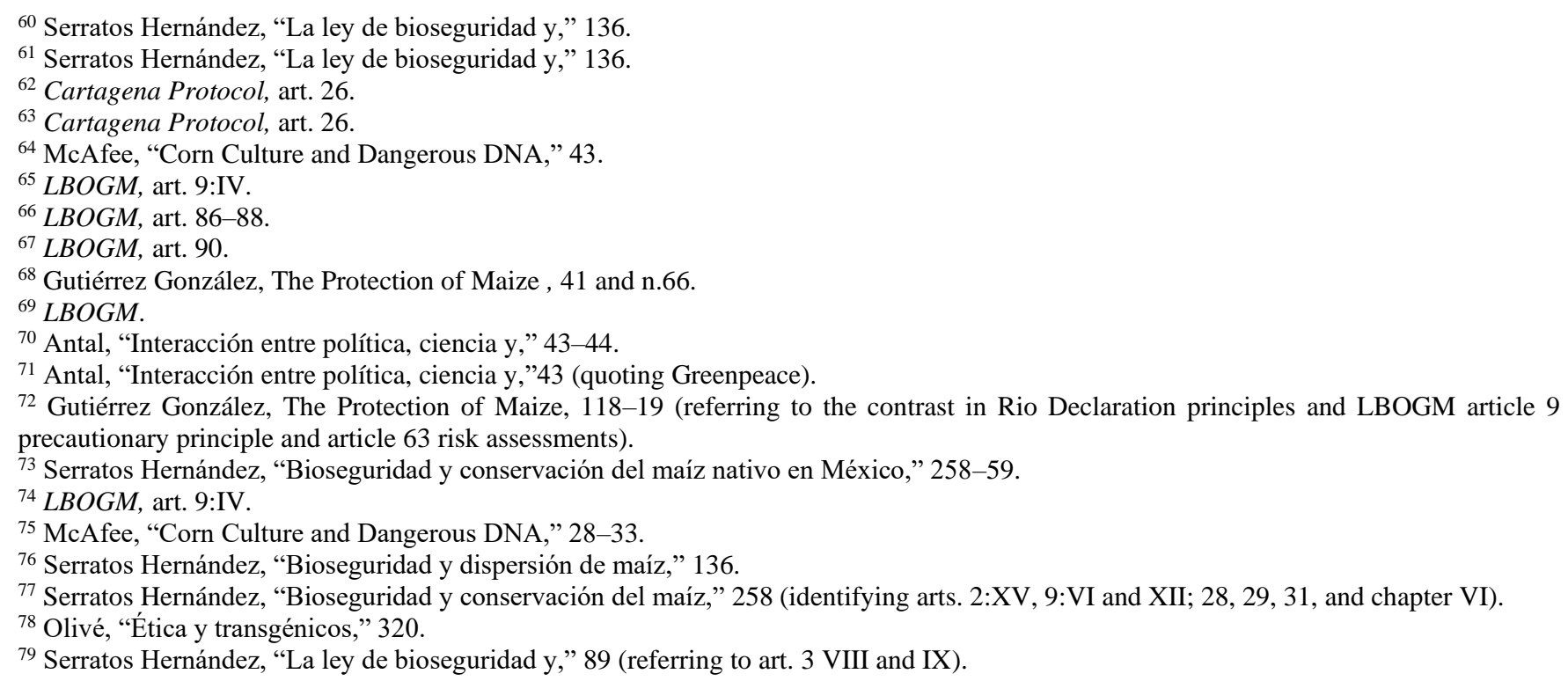


the criteria for a center of origin or a center of diversity in Articles 86 and 87 fails to meet the LBOGM's objectives. ${ }^{80}$ Further, it has been argued that the corn regime maps do not specifically identify where landrace corn is grown. ${ }^{81}$ Additionally, the Mexican regulations under which these maps for corn were developed were prepared without public input. The Secretary of Agriculture only solicited input from the biotechnology industry. This excluded scientists, corn farmers, and concerned members of the public from participation. ${ }^{82}$ The required notice for public comment about these regulations was ignored. ${ }^{83}$

The LBOGM's corn regime was delayed until 2009. ${ }^{84}$ As such, the regulations were not announced until four years after 2005 , and the corn origin and corn diversity regulatory maps were not issued for another three years (i.e., in 2012). Amidst these delays, the Secretary of Agriculture began issuing experimental GMO corn permits in 2009. ${ }^{85}$ Given the political and controversial nature of any GMO corn regulations, Mexican Presidents have been hesitant to introduce the required corn regime. ${ }^{86}$ Due to these delays (and the consequent lack of infrastructure to protect landrace corn), scientists see precautionary measures as the only way to protect landrace corn from GMO risks. ${ }^{87}$

Foreign seed companies have used these regulatory gaps to gain a foothold in México. They represent the overwhelming majority of actors soliciting GMO permits for corn and other products. In 2017, the Centro de Estudios para el Cambio en el Campo Mexicano (CECCAM) confirmed this after examining 30 years of GMO farming in México. ${ }^{88}$ It noted that 19 commercial permit requests for GMO corn were submitted, but because of the lawsuit, they have been suspended during the official process when "risk analyses" are conducted. ${ }^{89}$ The result is no permits have been issued.

Specific to GMO corn, foreign firms have made the most permit requests and have received the majority of approvals. CEECAM noted that there have been 327 requests for GMO non-commercial corn permits, of which 194 were approved and 42 denied. ${ }^{90}$ Monsanto or Dupont-Pioneer made 70 percent of the requests. ${ }^{91}$ Approvals were issued for 169 experimental permits and 26 pilot permits. ${ }^{92}$ All of these were non-commercial. In relation to non-corn GMO crops, 853 permit requests have been made. ${ }^{93}$ Monsanto made 44 percent of these requests. ${ }^{94}$ The government has recorded that 1 in 8 permit requests are denied, but that most GMO permit requests are approved by the Secretary of Agriculture. ${ }^{95}$

\section{b. Mexican Regulations Confront Dueling Perspectives}

Mexican law encompasses two possible approaches to GMO technology: the precautionary principle perspective and the managed risk perspective. The LBOGM refers to both approaches, but as described above, the default approach is to manage risks and minimize situations in which precautionary measures need to be employed. Since 2013, the courts have used their injunctive powers to employ precautionary measures. This is temporary and has been done pursuant to México's collective action law and not the LBOGM.

The precautionary principle and managed risk perspective represent distinct examples of how a legal instrument confronts technology. Normative differences in government policy result from each perspective. This article argues that different conceptual assumptions and objectives produce these alternatives. They either directly confront the harms of GMOs or classify them as manageable risks.

Under the precautionary principle approach, the regulatory subject is a collective rather than a specific permit applicant or an IP owner. The subject is centered on biodiversity. In relation to corn, the subject of the regulatory doctrine are landrace plants and the priority is reducing their exposure to transgenes from GMOs. This approach detains or prohibits the administrative

\footnotetext{
${ }^{80}$ Serratos Hernández, "La ley de bioseguridad y," 95.

81 de Ita, "Reservaciones de maiz."

82 Olivé, “Ética y transgénicos," 320.

${ }^{83}$ Rábago Dorbecker, "Litigio Estratégico Contra la Siembra;” Peralta, "La protección oficial del maíz,” 445.

${ }^{84}$ U.S. Department of Agriculture, Mexico: Mapping Mexican Corn.

85 U.S. Department of Agriculture, Mexico: 2010 Biotech Corn Permits Issued.

86 Foyer, "Mexican Biosafety," 13.

87 Álvarez-Buylla, El maíz en peligro ante los transgénicos, 155.

88 Sandoval Vázquez, Treinta años de transgénicos.

${ }^{89}$ Sandoval Vázquez, Treinta años de transgénicos.

90 Sandoval Vázquez, Treinta años de transgénicos, 12.

91 Sandoval Vázquez, Treinta años de transgénicos, 18.

92 Sandoval Vázquez, Treinta años de transgénicos, 12.

93 Sandoval Vázquez, Treinta años de transgénicos, 2.

94 Sandoval Vázquez, Treinta años de transgénicos, 9.

95 Sandoval Vázquez, Treinta años de transgénicos, 9.
} 
process for permit approvals. In relation to the subject-knowledge domain, the concern is for the future and biodiversity. The conceptual focus is to conserve biodiversity by placing a burden on or halting technology.

Importantly, the precautionary principle empowers regulation in the Global South. In negotiating the Cartagena Protocol, it was the Global South states that demanded the inclusion of a precautionary principle in the treaty. ${ }^{96}$ The pro-GMO and pro-industrial agriculture positions of the United States (U.S), Canada, and others drove these opposing objectives. By referring to the precautionary principle powers, these Global South states can point to international law to determine when to halt or prohibit biotechnology.

Critiques of the precautionary principle paint these measures as anti-innovation, emphasizing its negative effects in terms of encouraging trade and attracting investments from biotechnology and seed companies. This perspective capitalizes on the assumptions that science is inherently good and is not politically or commercially motivated, and that delaying it or controlling it is harmful. In debates about corn, this narrative raises issues related to ensuring food security, increasing farm productivity, and using GMOs to bolster food sovereignty. Alessandra Arcuri explains how precautionary measures, when accepted by biotechnology interests, could actually improve regulations. ${ }^{97}$ She notes that such measures may guarantee informed regulations and policies by balancing security or biodiversity with innovation.

With its case-by-case risk assessments and limiting precautionary controls, the LBOGM also adopted elements of the managed risk perspective and the notion of substantial equivalence from American law. In terms of food safety and biosecurity, regulators in the U.S. generally claim that GMOs are a substantial equivalent to traditional plants. ${ }^{98}$ According to this perspective, individual interests are the subject. The regulations try to avoid encumbering or detaining approvals for GMOs. The focus is not on the future and the spread of transgenes; rather, it is on how biodiversity protections negatively affect IP owners or permit applicants. Under this approach, legal instruments guarantee procedural rights in the solicitation of permit approvals. This builds on justifications related to the increased productivity of GMOs and the economic gain of seed companies.

Under this approach, the subject-knowledge domain relies on the idea that GMOs are safe and do not differ to landrace plants. Many scientific studies claim that GMOs are safe and often these positions are presented as part of a scientific consensus. ${ }^{99}$ However, scientific studies from various disciplines refute claims that GMOs are safe and deny any such consensus. ${ }^{100}$ It has been argued that GMO corn is not substantially equivalent to landrace corn. ${ }^{101}$ The normative reasoning for this rests on regulations and doctrines that attempt to protect individual versus collective needs. The LBOGM seeks to ensure that the procedural and evidentiary rights of the GMO permit applicants are protected. This is achieved by having permit approvals as the default and creating hurdles as precautionary measures.

The American approach of substantial equivalence attempts to craft regulations based on risks that can be quantified. ${ }^{102}$ Historically, the U.S. has opposed the precautionary principle. ${ }^{103}$ The substantial equivalence position requires proof that the risks can be quantified. The legal result of this is a burden for precaution that must be supported by evidence before imposing any control measures. ${ }^{104}$ According to this perspective, judges, regulators, and policy makers examine the scientific proof of the harm.

\section{Part III: Precautionary Measures Engender Politics That Oppose GMOs}

Recent Mexican developments in protecting landrace corn, maíz, nativo, open the door for Latour's suggestions. Latour contends that opposition to modernity and global forces are vital to combating the environmental crisis. ${ }^{105}$ Any such opposition is most likely to succeed when it is local and terrestrial. This article argues that the election of President Andrés Manuel López Obrador (AMLO), and the fact that the legislature is now controlled by the progressive coalition Movimiento Regeneración Nacional, colloquially referred to as MORENA, raise the possibility of GMO corn policy shifts. The victories of AMLO and MORENA in 2018 created space to capitalize on the six years of legal opposition by the Colectividad del Maíz and the public pressure it has inspired.

\footnotetext{
96 Meyer, "The Precautionary Principle," 3-5.

97 Arcuri, "Reconstructing Precaution, Deconstructing Misconceptions," 359.

98 Bratspies, "Some Thoughts," 405-14.

${ }^{99}$ National Academies of Sciences, Engineering, and Medicine, Distinction Between Genetic Engineering.

${ }^{100}$ Hilbeck, "No Scientific Consensus;" Domingo, "Safety Assessment of GM Plants;" Domingo, "A Literature Review."

101 Mesnage, "An Integrated Multi-Omics."

102 Acosta, "Restrictions on Genetically Modified Organisms."

103 Sands, "The 'Greening' of International Law," 301.

${ }^{104}$ Hunter, International Environmental Law and Policy, 479.

105 Latour, Down to Earth, 12.
} 
This article focuses on a new vision of agriculture policy, a public leadership that is critical of biotechnology, and debates in the legislature about protecting maíz nativo. Considered in decolonial terms, these developments could shape future subjectknowledge domains. These changes happen within coloniality, a dynamic that is both historic and current. One such option, a pro-GMO perspective, would be a subject that facilitates a transnational means to regulate GMOs. This effectively supports GMOs and limits México's options to employ precautionary principle. Coloniality adapts. The NAFTA in 1994, the LBOGM in 2005, and the USCMA in 2020 illustrate how the subject-knowledge domain changes over time. An alternative option, focused on precaution, develops if landrace corn is regarded as the subject. Its policy objectives would seek to protect biodiversity and avoid long-term transgene harms. This option is terrestrial, as its objective is to protect biodiversity rather than to support biotechnology, IP, or international trade.

First, AMLO called for a new vision of agriculture focused on supporting campesinos, rural economies, and subsistence farming to avoid displacements from corn imports and guarantee food security. ${ }^{106}$ In his campaign, AMLO proclaimed a Plan de Ayala $X X I$, referring to Emiliano Zapata's manifesto of 1911, which included an iconic declaration on property and resistance during the Mexican Revolution. ${ }^{107}$ For Zapata, the economic pressure posed by sugar farming for exports from Cuernavaca in the early twentieth century reflected nationwide frustrations with liberal land reforms. At the time, there was grounded opposition to foreign ownership and to breaking up ejidos (communal lands). Zapata's slogan "tierra y libertad" (land and liberty) captured these sentiments. AMLO's plan provided a conceptual reference point focused on the rural sector and offered governmental support to counter neo-liberal displacement.

Since being in office, AMLO has made specific promises. In his inauguration speech, in which he made 100 commitments, AMLO stated that the importation of GMO seeds would not be allowed and that small-scale farmers would receive new forms of support. ${ }^{108}$ AMLO and leading aides announced changes to the litigation position of the Government in Colectividad del Maíz, such that permits for GMO corn were not to be authorized. ${ }^{109}$ These commitments represent a larger vision for Mexican agriculture under which México would become self-sufficient in the production of corn and other crops. To help rural communities, price guarantees were implemented to benefit farm producers and consumers. ${ }^{110}$ The goal has been to improve rural livelihoods and counter the displacements caused by the neo-liberal reforms post 1988 and the NAFTA. ${ }^{111}$ This approach is terrestrial, as it incentivizes the sustainable economic use of the land by encouraging smaller plots and less industrial farming.

Notably, many corn activists have been critical of AMLO because, as of August 2020, there is still no actual policy banning GMO corn seeds and no conversion of the court orders in Colectividad del Maíz into permanent policy. This was most obvious a year after AMLO's victory when over 200 people and over 20 organizations issued a public letter calling for AMLO to ban GMOs. ${ }^{112}$ This letter included reform proposals, summaries of scientific evidence, an analysis of the legal authorities, and discussions of institutional means to implement the ban. ${ }^{113}$ Two years since AMLO's presidency began, these public critiques continue, expressing deeper frustrations. ${ }^{114}$

Second, upon entering office, AMLO appointed officials to cabinet, regulatory agencies, and research positions who were known to be critical of biotechnology and advocates of landrace corn. These appointments included leaders in the environmental and food policy agencies. ${ }^{115}$ These individuals have been vocal in seeking to stop GMO corn farming in México. Notably, these comprehensive perspectives are present in (and have the potential to influence) multiple governmental agencies. This differs from a situation in which positions critical of GMOs are limited to one agency or are held only by academic researchers. This has the potential to help make maíz nativo the subject in debates about agency positions, resource allocations, and litigation. Before the Colectividad del Maíz lawsuit, the subjects of Mexican biosecurity policy debates were biotechnology and increasing corn production, both of which were achieved via the LBOGM (2005), NAFTA (1994), and neo-liberal reforms in the countryside (since 1988).

The appointment of Dr. Elena Álvarez-Buylla to CONACYT illustrates the subject-knowledge dynamics at play. CONACYT is the primary agency responsible for funding scientific and academic research. Before her appointment, Álvarez-Buylla was an academic biology researcher with distinguished positions in México and overseas. Her publications served as vital sources

\footnotetext{
106 Wise, "Why Mexican Farmers are Hopeful."

107 Wise, "Making Rural Mexico Great Again."

108 Presidente Andrés Manuel López Obrador, "Mensaje a la Nación desde."

109 Agencia Reforma, "Gobierno busca prohibir cultivos transgénicos."

${ }^{110}$ Rodríguez García, "AMLO anuncia precios de garantía."

${ }^{111}$ Hansen-Kuhn, "Bold farm plans in Mexico."

112 Enciso, "Piden a AMLO emita decreto."

${ }^{113}$ Concha Malo, "Se solicita emitir decreto presidencial ."

${ }^{114}$ Escalona, "Por T-MEC."

115 TeleSur English, "AMLO's Government Pledges.”
} 
of support for the Colectividad's legal position. Biotechnology researchers and agriculture groups loudly protested her appointment, claiming that she would derail much needed innovation ${ }^{116}$ and noting that the country's food security and antihunger policies were at stake. Seen in decolonial terms, from these viewpoints, the biotechnology field was the subject at risk. For the biotechnology industry, its privilege includes governmental support for research and help in shaping food, agriculture, and trade policies.

Álvarez-Buylla has voiced alternative viewpoints; however, these viewpoints are not as extremist as her opponents have claimed. ${ }^{117}$ She emphasizes that biotechnology and GMOs are not intrinsically problematic, but that there are definite biodiversity risks from these technologies that require precaution. This is particularly relevant for México and corn, as it is the grain's center of origin and center of diversity. For centuries, knowledge and practices have preserved corn diversity. These practices and human efforts need to be protected to preserve landrace corn. Such practices are at risk due to biotechnology and IP protections in México. The alternative to Álvarez-Buylla's viewpoint is the prioritization of laboratory-based perspectives that benefit seed companies.

In recommending that precaution be exercised to nurture biodiversity and protect landrace corn, Álvarez-Buylla promotes a different vision of science. This reflects a terrestrial view of science, as it prioritizes the preservation of natural resources that serve farming needs. Álvarez-Buylla's vision incorporates indigenous knowledge and practices vital to nurture corn varietals 118 (e.g., seed saving and milpa, the centuries old tradition of growing a variety of corn plants on small plots). These concepts differ dramatically from the private ownership of genetic information intrinsic to the biotechnology that is needed for seed companies and industrial agriculture. Álvarez-Buylla's perspective emphasizes knowledge that is socially committed to Mexicans over the protection of corporate interests in GMOs, their permit approvals, and trade liberalization.

Third, the Mexican legislature has become more active in debates about protecting non-GMO corn. In such debates, two opposing positions exist. One side argues for the protection of landrace corn and sustainable farming. Conversely, the other side argues that Mexico's IP regime needs to be changed to conform with the USMCA and agro-industrial farming needs. An example of Latour's terrestrial politics can be seen in the legislature's passing of the Ley Federal para el Fomento y Protección del Maíz Nativo (LFFP) (the Federal Law for the Support and Protection of Maíz Nativo). ${ }^{119}$ For many Mexicans, this law reflects a national movement and popular saying, "Sin maíz, no hay país," which means "without corn there is no nation." This saying has been increasingly used in popular protests. ${ }^{120}$

The LFFP's objective is to protect access to landrace corn for Mexicans and the traditional practice of corn seed saving and exchanging. The LFFP specifically states that maíz nativo is a part of México's cultural heritage and reflects a human right to enjoy the sustainable use of the country's biodiversity. It further states that the national government should use its appropriate powers to protect landrace corn. The LFFP does not specifically ban GMO corn or seek to undo the LBOGM GMO corn permit process.

Those opposing the LFFP criticized the bill for its impact on household corn use. As the LFFP bill made its way to the lower house, public campaigns from opposition politicians and industrial agriculture argued that the LFFP would increase the price of tortillas by 70 percent $^{121}$ and that the bill would stop biotechnology innovations. ${ }^{122}$ Predictably, these concerns spread nationwide. In public terms, the opposition cast the national debate in terms of tortilla prices, food security, and technological progress. Conversely, advocates for landrace corn and the LFFP shifted the policy focus to national Mexican law. In decolonial terms, the advocates made maíz nativo the subject of these proposals.

The LFFP attempts to counter the USMCA, which provides ample support for biotechnology and effectively dilutes national precautionary principle powers. ${ }^{123}$ The USMCA is the first trade agreement negotiated by the U.S. that covers trade in biotechnology, including GMOs, gene editing and potential future developments. ${ }^{124}$ When implemented, the LFFP will introduce corn specific measures into Mexican law that counter additional IP protections from the USMCA.

\footnotetext{
116 Toledano, "Carta pública en respaldo al."

117 Wade, "New science minister's activism," 14

${ }^{118}$ Cassani, "Conversando con Elena Álvarez-Buylla."

119 Becerril, "Al Ejecutivo, la Ley para."

${ }^{120}$ Michail, "Sin Maíz No Hay País."

${ }^{121}$ Monroy, "Ley de maíz nativo incrementará."

122 Domínguez, "Nueva ley de maíz frena."

${ }^{123}$ Hernández Ordoñez, "La biotecnologiá agrícola en el T-MEC"

${ }^{124}$ USMCA, art. 3.12, p. 3-6.
} 
As an international agreement, the USCMA changes support for GMOs, likely requiring México to limit its options for precautionary controls. The USMCA does not directly abrogate any precautionary controls in Mexican law, including the LBOGM, the collective action law, or environmental treaties. When the NAFTA became effective in 1994, biotechnologies were not yet commercially available. At that time, it was predicted that the agreement would displace corn farmers in México. The NAFTA achieved this by reducing import tariffs to zero and by providing American subsidies for corn farmers. ${ }^{125}$ In decolonial terms, markets are the subject and the trade agreement is the corresponding authority domain. With these dynamics, coloniality justified the displacement of Mexican corn farms. Viewed historically, after 1910, Zapata and other revolutionary fighters responded violently to liberalism's rural land displacement. In 1994, the Ejérctio Zapatista de Liberación Nacional in Chiapas voiced its opposition to the NAFTA's market liberalization.

The present decolonial dynamic examines how the subject-knowledge domain is defined by referring to biotechnology or maíz nativo. These dynamics are not focused on land and markets. These dynamics now show how domestic regulation is shaped by international trade agreements or by national efforts that seek to employ sovereign precaution. Thus, transnational governance operates as the site of resistance and the violent struggles of 1910 and 1994 have been replaced with legislative efforts to regulate GMO corn.

Coloniality rests between precautionary protection and regulatory liberalization. In circumstances in which maíz nativo is the subject, justifications refer to individual rights in Mexican law related to biodiversity, cultural heritage, and food. The legal doctrine supporting this includes the LFFP, findings by courts in the Colectividad del Maíz, and positive law pronouncements of precautionary principle powers in the LBOGM and the Cartagena Protocol. Conversely, when biotechnology is the designated subject, the dynamic focuses on the USMCA, particularly in relation to Mexican trade commitments with the U.S. and Canada, and required legal obligations for IP protections for plants under international and Mexican law.

The USCMA tries to use coloniality to support GMO corn in two basic ways. First, it does so by explicitly favoring trade in biotechnology and second, by moving to harmonize biotechnology regulations, most importantly in the provision of IP protections for plants. In this respect, the USMCA uses transnational regulations and assumptions about science-based regulations to support GMOs. This article argues that determining the subject and thus the concepts that justify a trade agreement drives legal support for GMO corn. The U.S. is the largest exporter of corn to México and México is the world's largest importer of corn. American exporters and agriculture officials have been frustrated with the court injunctions in the Colectividad del Maíz since 2013. Thus, the USMCA's conceptual and legal framing (i.e., the subject-knowledge and authority domains) is vital to understand how legal doctrines have and are evolving to support biotechnology. This is done indirectly in the USMCA; rather, than explicitly in relation to corn, GMOs, tariffs, or precautionary powers.

First, Chapter 3 of the USMCA focuses on agriculture. It should be noted that while nothing specific is stated about corn, it effectively establishes a default position that supports biotechnology. It explains that the USMCA's objectives are to encourage trade in biotechnology and to not disrupt trade in biotechnology. ${ }^{126}$ In substantive terms, Chapter 3 increases the burden for any precautions by requiring an importing country to refute evidence from the biotechnology exporter. ${ }^{127}$ For example, if México wanted to control a low level transgene from American or Canadian GMO corn exports, Chapter 3 provides exporter with private interests the right to have Mexican regulators review the safety assessment evidence provided by the exporter. Further, the USCMA benefits the exporter by requiring that México must take into account any risk assessment made by U.S. or Canadian regulators. ${ }^{128}$ This effectively means the Mexican regulators would have to defer to foreign risk assessments or similar assessments by exporters.

Chapter 3 of the USCMA does not specifically refer to the precautionary principle; however, it does provide regulatory privileges for seed companies. For example, it requires that risk management should be undertaken "without unnecessary delay" and be "appropriate to achieve compliance with its laws and regulations." ${ }^{129}$ As an additional benefit that de-incentivizes precautionary principle measures, Chapter 3 states that the evidentiary requirements placed on importing countries, in this example, México, do not apply in relation to penalties. ${ }^{130}$ Thus, the USMCA tries to dissuade precautionary controls of transgene risks by requiring a series of evidentiary and procedural benefits for seed companies. However, by merely assigning penalties to these companies, they have avoided complex evidentiary debates over scientific risks, including debates related to host country regulations, the exporter's own scientific assessments, and determinations by other USMCA states. Conversely, if México assigned penalties, then GMO imports would not be prohibited and companies could absorb the economic costs. This

\footnotetext{
${ }^{125}$ Hernández-López, "Law, Food, and Culture,” 688.

${ }^{126}$ USMCA, art. 3.14, p. 3-7, 3-8.

${ }_{127}$ USMCA, art. $3.15: 2$, art. $3.15: 3$, p. 3-8, 3-9.

${ }^{128}$ USMCA, art. 3.15:3(d), p. 3-9.

${ }^{129}$ USMCA, art. 3.14:1, p. 3-7.

${ }^{130}$ USMCA, art. 3.16, p. 3-9.
} 
would address the fear related to closing the Mexican market, which has been the overwhelming American complaint since 2013, and would also evade any discussion of biodiversity, transgenes, or maíz nativo.

Second, the USMCA attempts to make biotechnology regulation increasingly similar across the three countries. It states that its objective is to encourage innovation and facilitate trade in products of agricultural biotechnology "while fulfilling legitimate objectives," including "transparency and cooperation." ${ }^{131}$ It has also established a three-country working group focused on biotechnology regulations. ${ }^{132}$

In substantive terms, the trade agreement attempts to harmonize IP rights protections for plants, which is the most direct concern for landrace corn protection. This has brought the debate to México's legislature. Agro-industrial interest groups have proposed the Federal Vegetable Variety Law (Ley Federal de Variedades Vegetales) (LFVV). ${ }^{13}$ The LFVV has been criticized for making seed saving and small-scale corn farming illegal to meet USMCA objectives. ${ }^{134}$ Presently, the policy debate in México is focused on if the LFVV will be passed. The USMCA has framed the conceptual terms of this dynamic.

The specific fear is that México needs to open up its market to GMO corn, as the USCMA requires IP protections for trade in corn from the U.S. or Canada. In terms of subject-knowledge domain, the USMCA shifts these requirements to another international agreement; that is, the 1991 version of the International Convention for the Protection of New Varieties of Plants (UPOV 1991). ${ }^{135}$ The LFVV is proposed as a Mexican law that would comply with the USMCA, in particular the UPOV 1991. México is a party to the former version of the UPOV convention; however, this version did not include most of the protections that GMO and biotechnology interest groups seek. Maíz nativo advocates argue that the UPOV 1991 dilutes the need for such protections, as it extends IP protections for plants from the current 10 years to 20 or 25 years. It also makes seed saving and seed exchanges illegal. ${ }^{136}$ These traditional and widespread practices of Mexican corn farmers are central to nurturing corn's biodiversity. The USMCA and the UPOV 1991 regard the subject as the IP protections needed for trade in plant seeds.

\section{Conclusion}

This article examined recent GMO corn developments in México to illustrate how the law supports biotechnology and to suggest how the law may limit biotechnology. Two methodological and descriptive arguments were made. First, in methodological terms, decolonial theory was used to identify how GMOs benefit from economic, legal, and conceptual assumptions. These domains work in unison to exert a transnational influence. In relation to maíz in México, support for GMOs relies on various protective legal doctrines, including cross-border IP protections, international trade commitments, and LBOGM regulations. Notably, conceptual assumptions protect this technology from precautionary controls. In decolonial terms, this exemplifies the subject-knowledge domain. GMO technologies benefit from various narratives, including increased productivity, scientific consensus, managed risks, and IP protections. The LBOGM, neo-liberal agricultural policies, and the NAFTA secure private property rights at the expense of precautionary controls being applied to GMOs.

The orders made by the courts in the Colectividad del Maíz lawsuit stopping commercial GMO corn raise a legal alternative. This collective legal action has enjoined commercial permits for GMO corn since 2013, and thus temporarily suspended permit reviews pending more court rulings. This gained worldwide attention, as Monsanto, Syngenta, Dow, and Pioneer-Dupont had this important market closed off due to biodiversity concerns. México is one of the world's largest markets for corn. It is also the center of origin and diversity for corn. Further, centuries of spiritual and cultural significance are attributed to the grain.

In decolonial terms, these precautionary controls suggest that different legal doctrines produce different normative results. Collective action, constitutional, and international environmental law doctrines support precaution. Conversely, biosecurity, IP, and trade law do not. In subject-knowledge terms, the Colectividad del Maíz's successes indicate that conceptual framing focused on long-term harms and biodiversity may potentially roll back legal support for GMOs. This requires an acknowledgement of the transgene harms and a de-prioritization of the IP rights embedded in biosecurity and trade law. This counters pro-GMO narratives about increased productivity and scientific consensus.

Second, the article used Latour's suggestions to predict what may occur, as the USMCA updates the NAFTA and political changes in México have led to calls to ban GMO corn. Latour's proposals for down to earth politics inspire political responses

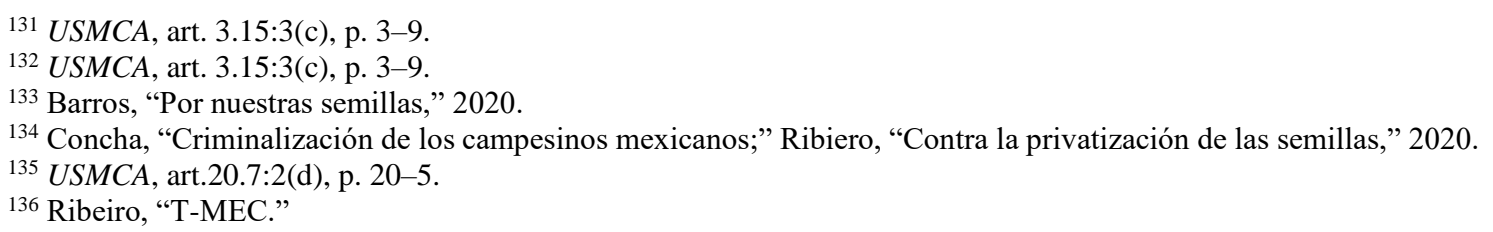


to regulate biotechnology. AMLO and other policymakers in México have voiced support for such a ban, but no actual policy bans GMO corn yet. The USCMA updates legal protections for GMO corn. The agreement does this by explicitly favoring trade in biotechnology and by harmonizing IP protections for plants, requiring México to accede to the UPOV 1991. In such circumstances, the decolonial dynamic must consider if the subject is biotechnology or maiz nativo. Historically, the focus of similar Mexican subject-knowledge dynamics was on land and markets. Presently, the dynamic asks how domestic regulation is shaped by international trade agreements or by efforts to employ precautionary protections. Currently, transnational governance operates as the site of resistance. Thus, the LFFP uses Latour's down to earth politics to protect maíz nativo and counter the USMCA's cross-border regulations. This debate continues domestically, as México waits for the resolution of the Colectividad del Maíz lawsuit and obligations in the USMCA to be implemented.

In conclusion, decolonial theory helps isolate how material interests, legal doctrines, and concepts facilitate or try to control new technologies. Legal scholars should use this methodology to make sense of the law's influence on emerging technologies, such as artificial intelligence, gene editing, biologic pharmaceuticals, industrial automation, and 5G communications. Latour's call for down to earth politics helps legal scholars identify what legislative reforms or political action may intercede when jurisprudence, regulations and doctrines are not sufficient.

\section{Acknowledgements}

The author would like to thank Rene Sanchez Galindo and Ana Ruiz Díaz of the Colectividad del Maíz for agreeing to be interviewed. The Author would also like to thank the two anonymous reviewers, and Boatema Boanteg, Michael Fakhri, James Gathii, James Hudson, Joanna Sax, and Ximena Sierra Camargo for reading earlier drafts and making suggestions, and the participants of Race + IP, NYU School of Law, the Annual Sustainability Conference, Arizona State University, the What Is Real About Law and Technology Workshop, Queensland University of Technology School of Law and LatCrit Biannual Conference for their suggestions.

\section{Bibliography}

\section{Primary Sources}

Cartagena Protocol on Biosafety to the Convention on Biological Diversity, 2226 U.N.T.S. 208, 39 I.L.M 102, (January 29, 2000).

CONACYT, "El presidente Andrés Manuel López Obrador asegura que no se permitirá la siembra de maíz transgénico en México," Comunicado 18/19, (March 11, 2019). https://www.conacyt.gob.mx/index.php/comunicados/964-com-18-1203-19

Concha Malo et al, Miguel. Se solicita emitir decreto presidencial para preservar la bioseguridad en México, (June 19, 2019). https://drive.google.com/file/d/1LdwvqHlEx1jXe6C3nRUsT76R9W_QBazg/view and https://consumidoresorganicos.org/2019/06/26/mexico-sin-transgenicos-bioseguridad/

Demanda colectiva del maíz, El devenir de la demanda de acción colectiva (complaint from the collective action), (July 5 , 2013). http://demandacolectivamaiz.mx/wp/demanda-contra-el-maiz-transgenico/

Juzgado Décimo Segundo de Distrito en Materia Civil del Distrito Federal, Nota Informativa, Acción colectiva contra la autorización de la liberación para comercializar maíz transgenico DGCS/NI: 41/2013, 14-10-2013 (México) (October 14, 2013).

Ley de Bioseguridad de Organismos Genéticamente Modificados (LBOGM), Diario Oficial de la Federacíon [DOF] 18-032005 (México). http://www.diputados.gob.mx/LeyesBiblio/pdf/LBOGM.pdf.

La Ley Federal Para El Fomento y Protección del Maíz Nativo (LFPP). Gaceta del Senado, LXIV/1SPO-128/94786, (April 25, 2019). https://www.senado.gob.mx/64/gaceta_del_senado/documento/94786

Presidente Andrés Manuel López Obrador, "Mensaje a la Nación desde el Zócalo de la Ciudad de México Mensaje a la Nación desde el Zócalo de la Ciudad de México," Gobierno de México, (Dec. 1, 2018). https://www.gob.mx/presidencia/articulos/discurso-de-andres-manuel-lopez-obrador-presidente-de-los-estados-unidosmexicanos?idiom $=\mathrm{es}$

Toledano et al, Francisco. "Carta pública en respaldo al proyecto del CONACYT," (March 15, 2019). http://www.biodiversidadla.org/Campanas-y-Acciones/Carta-publica-en-respaldo-al-proyecto-del-CONACYT

U.N. Conference on Environment and Development, Rio Declaration on Environment and Development, JU.N. Doc. A/CONF. 151/5/Rev/1 reprinted in 31 I.L.M. 874, (June 14, 1992).

U.S. Department of Agriculture, Foreign Agriculture Service, Mexico: Agricultural Biotechnology Annual: Uncertain Future for Mexican Agricultural Biotechnology, GAIN MX8050 (2018). 
U.S. Department of Agriculture, Foreign Agriculture Service, Mexico: Mapping Mexican Corn and Implications for Biotech Development, GAIN MX1100 (2011).

U.S. Department of Agriculture, Foreign Agriculture Service, Mexico: Centers of Origin for Corn Published in Federal Register, GAIN MX2082 (2012).

U.S. Department of Agriculture, Foreign Agriculture Service, Mexico: 2010 Biotech Corn Permits Issued, GAIN, MX1102 (2011).

USCMA, Agreement between the United States of America, the United Mexican States, and Canada. https://ustr.gov/tradeagreements/free-trade-agreements/united-states-mexico-canada-agreement/agreement-between (December 13, 2019).

\section{Secondary Sources}

Acosta, Luis. Restrictions on Genetically Modified Organisms: United States. Law Library of Congress (last updated June 9, 2015). https://www.loc.gov/law/help/restrictions-on-gmos/usa.php

Agencia Reforma, "Gobierno busca prohibir cultivos transgénicos," debate.com.mx, February 18, 2019. https://www.debate.com.mx/mexico/Gobierno-busca-prohibir-cultivos-transgenicos--20190218-0114.html

Álvarez-Buylla, Elena and Alma Piñeyro-Nelson. El maíz en peligro ante los transgénicos. México: UNAM, 2013.

Antal, Edit. "Interacción entre política, ciencia y sociedad en biotecnología. La regulación de los organismos genéticamente modificados en Canadá y México.” Norteamerica, 3, no 1 (2008): 11-63. https://doi.org/10.22201/cisan.24487228e.2008.01.63

Applegate, John S. "The Taming of the Precautionary Principle." William and Mary Environmental Law and Policy Review 27, no 1 (2002): 13-78.

Arcuri, Alessandra. "Reconstructing Precaution, Deconstructing Misconceptions." Ethics and International Affairs 21, no 3 (2007): 359-379. https://doi.org/10.1111/j.1747-7093.2007.00104.x

Atapattu, Sumudu. "The Significance of International Environmental Law Principles in Reinforcing or Dismantling the North-South Divide." In International Environmental Law and the Global South, edited by Shawkat Alam, Sumudu Atapattu, Carmen G. Gonzalez, and Jana Razzaque, 74-108. London: Cambridge, 2015.

Barros, Cristina. "Por nuestras semillas," La Jornada del Campo. July 18, 2020. https://www.jornada.com.mx/2020/07/18/delcampo/articulos/nuestras-semillas.html

Becerril, Andrea and Víctor Ballinas. "Al Ejecutivo, la Ley para la Protección del Maíz Nativo.” La Jornada, March 26, 2020. https://www.jornada.com.mx/2020/03/26/politica/009n1pol

Bratspies, Rebecca. "Some Thoughts on the American Approach to Regulating Genetically Modified Organisms." Kansas Journal of Law and Public Policy 16, no 3 (2007): 101-131.

Cassani, Emiliano. "Conversando con Elena Álvarez-Buylla: México podría ser un granero de maíz de calidad para el mundo," Forum: Noticias del Foro Consultivo, no 32 (January 2018): 8-17.

Castro-Gómez, Santiago. La Poscolonialidad Explicada a Los Niños. Bogota: Universidad Javeriana, 2005.

Concha, "Criminalización de los campesinos mexicanos," La Jornada, October 12, 2019. https://www.jornada.com.mx/2019/10/12/opinion/014a1pol

Concha, Miguel. "Siete años defendiendo el maíz nativo.” La Jornada, July 11, 2020. https://www.jornada.com.mx/2020/07/11/opinion/024a1pol

CE NAFTA 2.0 (Spanish). "El precio de la tortilla no aumentará a 60 pesos por kilo si aprueban la nueva ley del maíz," November 11, 2019.

Coronil, Fernando. "Naturaleza del poscolonialismo: del eurocentrismo al globocentrismo." In La colonialidad del saber: Eurocentrismo y Ciencias Sociales Perspectivas latinoamericanas, edited by Edgardo Lander, 87-112. Buenos Aires: Consejo Latinoamericano de Ciencias Sociales, 2004.

de Ita, Ana. "Reservaciones de maíz: los centros de origen y diversidad." La Jornada, December 4, 2011. https://www.jornada.com.mx/2011/12/04/economia/024a1eco

Domingo, José L. "Safety Assessment of GM Plants: An Updated Review of the Scientific Literature." Food and Chemical Toxicology, 95 (2016): 12-18. http://dx.doi.org/10.1016/j.fct.2016.06.013

Domingo, José L. and Jordi Giné Bordonaba. "A Literature Review on the Safety Assessment of Genetically Modified Plants." Environmental International 37, no 4 (2011): 734-742. https://doi.org/10.1016/j.envint.2011.01.003

Domínguez, Leonardo. "Nueva ley de maíz frena la biotecnologia," El Universal, October 14, 2019. https://www.eluniversal.com.mx/ciencia-y-salud/ciencia/nueva-ley-de-maiz-frena-la-biotecnologia

Emerging Markets Online. "Mexican Agricultural Production to Expand but AMLO Reforms too Ambitious," https://www.fitchsolutions.com/corporates/commodities/mexican-agricultural-production-expand-amlo-reforms-tooambitious-30-07-2019 
Enciso, Angélica L. "Fase de presentación de pruebas: Sin respuesta de Sagarpa y Semarnat, acción colectiva contra transgénicos.” La Jornada, March 28, 2019. https://www.jornada.com.mx/2019/03/28/sociedad/036n1soc\#

Enciso L., Angélica. "Piden a AMLO emita decreto para prohibir cultivo de transgénicos," La Jornada, June $27,2019$. https://www.jornada.com.mx/2019/06/27/sociedad/038n1soc

Enciso, Angélica L. “Transnacionales buscan apoderarse del territorio para sembrar transgénicos.” La Jornada, February 16, 2018. https://www.jornada.com.mx/2018/02/16/sociedad/033n1soc

Escalona, Nayeli. "Por T-MEC, exigen a AMLO decreto que prohíba transgénicos," Contralinea, July 7, 2020. https://www.contralinea.com.mx/archivo-revista/2020/07/07/por-t-mec-exigen-a-amlo-decreto-que-prohiba-transgenicos/

Excelsior. "Monsanto aclara: biotecnología se utiliza de forma segura.” June 21, 2019. https://www.excelsior.com.mx/nacional/monsanto-aclara-biotecnologia-se-utiliza-de-forma-segura/1320031

Fitting, Elizabeth. The Struggle for Maize. Durham: Duke University Press, 2010.

Flores, Efrén, "México se inundó en 30 años con transgénicos de monopolios, y hoy sólo 4 estados están "libres." Biodiversidad LA, March 9, 2018. http://www.biodiversidadla.org/Documentos/Mexico_se_inundo_en_30_anos_con_transgenicos_de_monopolios_y_hoy solo 4 estados estan libres

Foyer, Jean and Christophe Bonneuil. "Mexican Biosafety as 'Performance of Seriousness': Distancing and the Transgenic 'Contamination' of Mexican Maize.” HAL Paper No. 01092208, December 8, 2014. https://halshs.archivesouvertes.fr/halshs-01092208/

García Sánchez, José. "Maíz debe resguardarse del T-MEC,” Regeneración, September 29, 2019. https://www.regeneracion.com/maiz-debe-resguardarse-del-t-mec/

Grosfoguel, Ramón. "Decolonizing Post-Colonial Studies and Paradigms of Political-Economy: Transmodernity, Decolonial Thinking, and Global Coloniality." Transmodernity: Journal of Peripheral Cultural Production of the Luso-Hispanic World 1, no 1 (2011): 1-38. http://escholarship.org/uc/item/21k6t3fq

Gutiérrez González, Alicia. The Protection of Maize under the Mexican Biosafety Law. Gottingen: Universitatsdruck Gottingen, 2010.

Gupta, Aarti and Robert Falkner. "The Influence of the Cartagena Protocol on Biosafety: Comparing Mexico, China, and South Africa." Global Environmental Policy 6, no 4 (2006): 23-55. https://doi.org/10.1162/glep.2006.6.4.23

Hansen-Kuhn, Karen. "Bold Farm Plans in Mexico Offer a Ray of Hope in 2019." IATP Blog, January 15, 2019. https://www.iatp.org/blog/201903/bold-farm-plans-mexico-offer-ray-hope-2019

Hernández-López, Ernesto. "GMO Corn in México: Law’s Coloniality." Vanderbilt Journal of Entertainment and Technology Law 22, no 4 (2020): 725-783.

Hernández-López, Ernesto. "Law, Food, and Culture: Mexican Corn's National Identity Cooked in "Tortilla Discourses" Post-TLC/NAFTA," St. Thomas Law Review 20, no 3 (2008): 670-688.

Hernández Ordoñez, Sergio Ricardo. "La biotecnologiá agrícola en el T-MEC: un contenido posiblemente asimétrico," Foreign Affairs: Latinoamérica, November 10, 2019. http://revistafal.com/la-biotecnologia-agricola-en-el-t-mec-uncontenido-posiblemente-asimetrico/

Herrera Izaguirre, Juan Antonio and Carlos Hinojosa, Gloria Hagelsieb, and René Salinas. “Mexico’s Environmental Law in the GMO Era." Mexican Law Review 1, no 1 (2008): 121-156.

Hilbeck, Angelika and Rosa Binimelis, Nicolas Defarge, Ricarda Steinbrecher, András Székács, Fern Wickson, Michael Antoniou, Philip L Bereano, Ethel Ann Clark, Michael Hansen, Eva Novotny, Jack Heinemann, Hartmut Meyer, Vandana Shiva and Brian Wynne. "No Scientific Consensus on GMO Safety." Environmental Science Europe 27, no 4 (2015): 16. https://doi.org/10.1186/s12302-014-0034-1

Hunter, David and James Salzman and Durwood Zaelke. International Environmental Law and Policy. New York: Foundation Press, 2015.

Jasanoff, Sheila. "Biotechnology and Empire: The Global Power of Seeds and Science.” Osiris 21, (2006): $273-292$.

La Otra Opinión. "Víctor Villalobos: el Secretario de Agricultura de AMLO experto en transgénicos," September $26,2018$. https://laotraopinion.com.mx/victor-villalobos-el-secretario-de-agricultura-de-amlo-experto-en-transgenicos/

Latour, Bruno. Down to Earth: Politics in the New Climatic Regime. New York: Polity, 2018.

McAfee, Kathleen. "Corn Culture and Dangerous DNA: Real and Imagined Consequences of Maize Transgene Flow in Oaxaca." Journal of Latin American Geography 2, (2003): 18-42.

Mesnage, Robin and Sarah Z. Agapito-Tenfen, Vinicius Vilperte, George Renney, Malcolm Ward, Gilles-Eric Séralini, Rubens O. Nodari and Michael N. Antoniou. "An Integrated Multi-Omics Analysis of the NK603 RoundupTolerant GM Maize Reveals Metabolism Disturbances Caused by the Transformation Process." Science Reports 6, no 37855 (December 19, 2016) https://www.nature.com/articles/srep37855

Meyer, Harmut. "The Precautionary Principle and the Cartagena Protocol on Biosafety: Development of a Concept." In Biosafety First, edited by Terje Traavik and Li Ching Lim. Oslo: Fagbokforlaget, 2007. 
Michail, Niamh. "Sin Maíz No Hay País: Mexican Law Seeks to Protect Native Corn," Food Navigator-Latam, November, 27, 2019. https://www.foodnavigator-latam.com/Article/2019/11/27/Sin-Maiz-No-Hay-Pais-Mexican-law-seeks-toprotect-native-corn

Mignolo, Walter D. "Introduction: Coloniality of Power and De-Colonial Thinking." Cultural Studies 21, (2007): $155-167$.

Monroy, Jorge. "Ley de maíz nativo incrementará precio de la tortilla, alertan productores," El Economista, November 5, 2019. https://www.eleconomista.com.mx/politica/Ley-de-maiz-nativo-incrementara-precio-de-la-tortilla-en-30-alertanproductores-20191105-0027.html

Moraña, Mabel and Enrique Dussel and Carlos A. Jáuregui. Coloniality at Large. Durham: Duke University Press, 2008.

Mullaney, Emma Gaalas. "Geopolitical Maize: Peasant Seeds, Everyday Practices, and Food Security in Mexico.” Geopolitics 19, (2014): 406-430. https://doi.org/10.1080/14650045.2014.920232

Nadal, Alejandro. "Mexico's Corn-Producing Sector: A Commentary." Agriculture and Human Values 23, (2006): 33-36.

National Academies of Sciences, Engineering, and Medicine. "Distinction between Genetic Engineering and Conventional Plant Breeding Becoming Less Clear, Says New Report on GE Crops.” National Academies of Sciences, Engineering, and Medicine, May 17, 2016. https://www.nationalacademies.org/news/2016/05/genetically-engineered-crops-experiencesand-prospects-new-report

Olivé et al, Leon and Jorge Linares, Yolanda Massieu and Leonara Milán. "Ética y transgénicos: el caso del maíz en México." In El maíz en peligro ante los transgénicos, edited by Elena Álvarez-Buylla and Alma Piñeyro-Nelson, $313-$ 332. México: UNAM, 2013.

Ortiz-García, Sol and Exequiel Ezcurra, Bernd Schoel, Franisca Acevedo, Jorge Soberón, and Allison A. Snow. "Letter to the Editor, Transgenic Maize in Mexico.” BioScience 56, (2006): 709-710.

Pellegrino, Elisa and Stefano Bedini, Marco Nuti and Laura Ercoli. "Impact of Genetically Engineered Maize on Agronomic, Environmental and Toxicological Traits: A Meta-Analysis of 21 Years of Field Data.” Science Reports 8, no 3113 (February 15, 2018). https://www.nature.com/articles/s41598-018-21284-2

Peralta, Lizy and Marielle, Catherine. "La protección oficial del maíz frente los transgénicos: una simulación de estado.” In El maíz en peligro ante los transgénicos, edited by Elena Álvarez-Buylla and Alma Piñeyro-Nelson, 441-443. México: UNAM, 2013.

Pilcher, Jeffrey. Que vivan los tamales: food and the making of Mexican Identity. Albuquerque: University of New Mexico Press, 1998.

Piñeyro-Nelson, Alma. "Un ejemplo de controversia científica: El debate en torno a la introducción de maíz genéticamente modificado en México." In Naturaleza, Ciencia y Sociedad: 40 años de pensamiento crítico interdisciplinario en la Facultad de Ciencias, edited by Fabrizzio Guerrero McManus, Octavio Valadez Blanco and Eduardo Vizcaya Xilotl, 91104, México: UNAM, 2016.

Piñeyro-Nelson, A and J. Van Heerwaarden, H. R. Perales, J. A. Serratos-Hernández, A. Rangel, M. B. Hufford, P. Gepts, A. Garay-Arroyo, R. Rivera-Bustamante E. R. Álvarez-Buylla. "Transgenes in Mexican Maize: Molecular Evidence and Methodological Considerations for GMO Detection in Landrace Populations.” Molecular Ecology 18, no 4 (2009): 750761. https://dx.doi.org/10.1111\%2Fj.1365-294X.2008.03993.x

Quijano, Aníbal. “Coloniality and Modernity/Rationality.” Cultural Studies 21, nos. 2-3 (2007): 168-178. https://doi.org/10.1080/09502380601164353

Quijano, Aníbal. “Coloniality of Power, Eurocentrism, and Latin America.” Nepantla: Views from the South 1, no 3 (2000): 533-580.

Rábago Dorbecker, Miguel and Graciela Rodriguez, Luis Miguel Cano and Luis Fernando Garcia. "Litigio Estratégico Contra la Siembra de Maíz Genéticamente Modificado en México." University of Miami Inter-American Law Review 43, no 1 (2011): 269-290.

Ribeiro, Silvia. “T-MEC: al peor pastor.” La Jornada, June 22, 2019.

Ribeiro, Silvia. "Contra la privatización de las semillas.” La Jornada, December 7, 2019.

Rodriguez, Cristian. "59 variedades de maíz mexicano peligran frente a maíz transgénico: CECCAM, UDGTV.” \#44LAB, Apreil 26, 2019. http://udgtv.com/44lab/maiz-mexicano-peligra-frente-a-transgenico/

Rodríguez García, Arturo. "AMLO anuncia precios de garantía a productores y baja en canasta básica de Diconsa y Liconsa," Proceso, September 30, 2019. https://www.proceso.com.mx/601478/amlo-anuncia-precios-de-garantia-a-productores-ybaja-en-canasta-basica-de-diconsa-y-liconsa

Sands, Philippe. “The 'Greening' of International Law: Emerging Principles and Rules.” Indiana Journal of Global Studies 1, (1994): 293-323.

Sandoval Vázquez, Daniel. Treinta años de transgénicos en México (compendio cartográfico), México: Centro de Estudios para el Cambio en el Campo Mexicana (2017). http://ceccam.org/sites/default/files/30_años_transgenicos.pdf

Serratos Hernández, José Antonio. “Bioseguridad y dispersion ispersionn de maíz transgénico en México.” Ciencias, no $92-$ 93, March, 2008: 130-141. 
Serratos Hernández, José Antonio. "La ley de bioseguridad y los centros de origen y diversificación.” In Origen y Diversificación del Maíz, edited by Takeo Ángel Kato Yamakake, Cristina Mapes Sánchez, Luz María Mera Ovando, José Antonio Serratos Hernández, and Robert Arthur Bye Boettler, 87-96. México: UNAM 2009.

Serratos Hernández, José Antonio and Dolores Fuentes, Alejandra Celeste. "Bioseguridad y conservación del maíz native en México." in El maíz en peligro ante los transgénicos, edited by Elena Álvarez-Buylla and Alma Piñeyro-Nelson, 249278. México: UNAM, 2013.

Steve, Oscar. "México se está quedando atrás en transgénicos según Cinvestav, aunque AMLO ha anunciado su rechazo total a ellos." Xataka, March 12, 2019. https://www.xataka.com.mx/investigacion/mexico-se-esta-quedando-atras-transgenicoscinvestav-amlo-ha-anunciado-su-rechazo-total-a-ellos

TeleSur English, “AMLO’s Government Pledges to Ban GMO Corn.” TeleSur, August 23, 2018. https://www.telesurenglish.net/news/AMLOs-Government-Pledges-to-Ban-GMO-Corn-20180823-0003.html

Usla, Héctor. "Sader descarta impacto en el precio de la tortilla ante ley que busca proteger al maíz nativo," El Financiero, November 11, 2019. https://elfinanciero.com.mx/economia/sader-descarta-impacto-en-el-precio-de-la-tortilla-ante-leyque-busca-proteger-al-maiz-nativo

Vats, Anjali and Deidré A. Keller. "Critical Race IP.” Cardozo Arts and Entertainment Law Journal 36, no 3, (2018): 735795.

Wade, Lizzie. "New science minister's activism sparks debate," Science 362 (October 4, 2018): 14-15.

Wise, Timothy. "Making Rural Mexico Great Again: Leading Candidate Endorses Farmers' Reform Program,” Food Tank, April 10, 2018. https://foodtank.com/news/2018/04/andres-manuel-lopez-obrador-regeneration-mexico-rural-agriculturetim-wise/

Wise, Timothy. “Why Mexican Farmers Are Hopeful about López Obrador’s Win.” Food Tank, July, 2018. https://foodtank.com/news/2018/07/mexico-president-lopez-obrador-nafta/ 